\title{
Pengaruh Ekstrak Ubi Jalar Ungu (Ipomoea Batatas L.) terhadap Kadar Superoksida Dismutase (Sod) Tikus Putih Jantan (Rattus Norvegicus) Galur Wistar Model Aterosklerosis
}

\author{
Effect of Purple Sweet Potato Extract (Ipomoea Batatas L.) on Superoxide Dismutase (Sod) Levels \\ of Male White Rats (Rattus Norvegicus) Wistar Strain Model of Atherosclerosis
}

\author{
M. Setiawan', E F. Rahadi \\ ${ }^{1}$ Staf Pendidik Ilmu Penyakit Dalam Fakultas Kedokteran, Universitas Muhammadiyah Malang \\ ${ }^{2}$ Program Profesi Dokter Fakultas Kedokteran, Universitas Muhammadiyah Malang \\ *Penulis koresponesi:Meddy Setiawan. Email: meddy_umm@yahoo.com
}

\begin{abstract}
ABSTRAK
Latar Belakang: Penyakit jantung koroner (PJK) merupakan penyakit jantung yang terutama disebabkan karena penyempitan arteri koronaria akibat proses aterosklerosis. Faktor yang berpengaruh terhadap pembentukan plak aterosklerosis adalah radikal bebas. Ekstrak ubi jalar ungu memliki kandungan antosianin, beta glukan dan assam askorbat sebagai antioksidan, diharapkan dapat menghambat radikal bebas sehingga plak aterosklerosis tidak terbentuk. Penelitian ini bertujuan untuk mengetahui pengaruh pemberian ekstrak ubi jalar ungu (Ipomoea batatas L.) terhadap kadar superoksida dismutase SOD tikus jantan putih (Rattus norvegicus) galur wistar model aterosklerosis.

Metode: Metode yang digunakan dalam penelitian ini true experimental, post-test only control group design dengan kelompok kontrol negatif, kontrol positif, serta 3 kelompok perlakuan ekstrak ubi jalar ungu yaitu dosis $24 \mathrm{mg} / \mathrm{hari}$, $48 \mathrm{mg} / \mathrm{hari}, 96 \mathrm{mg} / \mathrm{hari}$.

Hasil: Hasil uji one way anova adalah $\mathrm{p}=0,001(\mathrm{p}<0,05)$, yakni terdapat perbedaan signifikan. Hasil uji post-hoc didapatkan konotasi berbeda antar kelompok. Hasil uji korelasi terdapat hubungan yang kuat yaitu $p=0,000(p<0,05)$. Pada uji regresi linier didapatkan $\mathrm{R} 2=0.65$. Berdasarkan hasil uji yang dilakukan menunjukkan semakin tinggi dosis ekstrak yang diberikan, semakin tinggi kadar SOD.

Kesimpulan: Terdapat pengaruh antara pemberian ekstrak ubi jalar ungu (Ipoema batatas L.) terhadap peningkatan kadar superoksida dismutase (SOD) tikus jantan putih (Rattus norvegicus) galur wistar model aterosklerosis.
\end{abstract}

Kata kunci: Aterosklerosis, stres oksidatif, SOD, ekstrak ubi jalar ungu (Ipomoea batatas L.)

\begin{abstract}
Background: Coronary heart disease (CHD) is a heart disease which mainly caused by atherosclerosis; narrowing of the coronary arteries One of the factors that influence the formation of atherosclerotic plaque is radical-free substance. Purple sweet potato extracts is consist of antochyanin, beta glucan and ascorbic acid as antioxidants that are expected to inhibit the free radicals to prevent the formation of atherosclerotic plaques. The purpose of the experiment is to prove that purple sweet potatoes (Ipomoea batatas L.) extract takes effect towards SOD level in atheroclerosis model of white male rats (Rattus novergicus) wistar strain.

Method: The method of this experiment was true experimental, post-test only control group design with group of negative control, positive control, and 3 groups of purple sweet potatoes extract treatment with 24mg/day, 48/mg/day, 96mg/day doses.

Results: The result of one way Anova Test $p=0,001(p<0,05)$ had significant difference.The result of Post Hoc Test had different conotation among groups. The result of Correlation Test has strong correlation that is $p=0,000(p<0,05)$. In Regression Linier Test showed R2=0.65. Based on the results of the test showed that the higher dose of the extract is given, the higher level of rats' SOD.

Conclusion: Administration of purple sweet potatoes (Ipomoea batatas L.) extract takes effect to increase SOD level in atherosclerosis model of white male rats (Rattus novergicus) wistar strain.
\end{abstract}

Keywords: Atherosclerosis, oxidative stress, SOD, Purple sweet potato. 


\section{PENDAHULUAN}

Penyakit jantung koroner (PJK) merupakan penyakit jantung yang terutama disebabkan karena penyempitan arteri koronaria akibat proses aterosklerosis ${ }^{1}$. Salah satu faktor risiko untuk penyakit aterosklerosis yaitu kolesterol Low Density Lipoprotein (LDL) yang tinggi. ${ }^{2}$ Penyakit ini menyebabkan kematian sebanyak 7,4 juta jiwa di seluruh dunia. $^{3}$ Prevalensi PJK di Indonesia tahun 2013 diperkirakan sekitar 883.447 orang. ${ }^{4}$ Radikal bebas adalah molekul yang bersifat tidak stabil, dan diproduksi oleh tubuh kita sebagai bagian dari metabolisme normal tubuh kita. Reaksi radikal bebas yang berikatan dengan LDL akan menghasilkan ox- $L D L$ (Oxidation Low Density Lipoprotein) yang memiliki peran penting dalam pembentukan plak aterosklerosis. $^{5}$

Antioksidan dapat membantu tubuh mengatasi radikal bebas yang bekerja dengan cara menetralisir radikal bebas. Superoksida dismutase (SOD) adalah salah satu antioksidan endogen yang diproduksi oleh tubuh. ${ }^{6}$ Berbagai penelitian dilakukan untuk memanfaatkan tanaman herbal sebagai alternatif untuk pencegahan terhadap aterosklerosis salah satunya adalah ubi jalar ungu. Ubi jalar ungu mengandung antioksidan yaitu pigmen antosianin, asam askorbat, dan beta glukan yang lebih tinggi dibanding ubi jalar yang lain Antioksidan pada ubi jalar ungu memiliki fungsi fisiologis sebagai anti kanker, anti mutagenik, anti hipertensi perlindungan terhadap kerusakan hati, penyakit jantung dan pembuluh darah, dan stroke. ${ }^{7}$

Ubi jalar ungu sudah dikenal secara umum di masyarakat sebagai salah satu umbi-umbian yang dimanfaatkan sebagai makanan tambahan sehari-hari. Ubi jalar ungu dapat tumbuh di seluruh wilayah Indonesia, bahkan ubi jalar menjadi tanaman pokok di Papua dan beberapa daerah di Indonesia. ${ }^{8}$ Sementara sisi lainnya, masyarakat Papua mayoritas mengonsumsi babi yang mengandung asam lemak jenuh dan kolesterol. ${ }^{9}$ Sebagaimana kita ketahui babi memiliki kandungan kolesterol yang sangat tinggi sehingga sangat beresiko terhadap penimbunan plak aterosklerosis. Namun berdasarkan data riset kesehatan dasar 2013, Jumlah penderita penyakit jantung koroner provinsi Papua adalah yang paling sedikit yaitu sebanyak 6.690 orang. ${ }^{4}$

Berdasarkan uraian latar belakang diatas, peneliti tertarik untuk menguji pengaruh ekstrak ubi jalar ungu sebagai antioksidan terhadap kadar SOD pada tikus putih jantan (Rattus norvegicus) galur wistar model aterosklerosis.

\section{METODE PENELITIAN}

Penelitian true experimental dengan menggunakan metode Post Test Only Control Group Design. Penelitian ini bertempat di Laboratorium Biomedik selama 8 minggu. Populasi dalam tikus ini adalah tikus putih jantan (Rattus norvegicus) galur wistar. Sampel yang digunakan adalah tikus putih jantan strain wistar (Rattus norvegicus) galur wistar dengan berat 150-200 gram dan berusia 2-3 bulan dengan kondisi sehat yang ditandai dengan gerakan yang aktif dan mata jernih. Peneliti menetapkan Kelompok perlakuan terdiri 5 kelompok yaitu, satu kelompok kontrol normal, kontrol negatif, perlakuan 1 (P1), perlakuan 2 (P2) dan perlakuan 3 (P3) dengan masing-masing kelompok terdapat 5 ekor tikus ditambah dengan 2 ekor tikus cadangan. Prosedur penelitian ini diawali dengan proses aklimatisasi selama 7 hari dengan diberikan pakan standar BR-1 ditambah air minum ad libitum. Selanjutnya pada kelompok kontrol + serta perlakuan 1, perlakuan 2 dan perlakuan 3 diberi diet hiperkolesterolemia. Diet hiperkolesterolemia terdiri dari pakan standar yang ditambah kolesterol $2 \%$, asam kolat $0,2 \%$ dan minyak babi 5\%. Pemberian ekstrak ubi jalar ungu pada perlakuan 1, perlakuan 2 dan perlakuan 3 masing-masing dosis $24 \mathrm{mg} / \mathrm{hr}, 48 \mathrm{mg} / \mathrm{hr}$ dan $96 \mathrm{mg} / \mathrm{hr}$. Selanjutnya setelah 8 minggu dilakukan pembedahan pada tikus untuk diambil serum darah pada tiap sampel tikus, kemudian dilakukan pemeriksaan kadar SOD diukur dengan spektofotometri. Setelah didapatkan data, kemudian dilakukan analisis 
dengan uji one way ANOVA, post hoc test, uji korelasi dan regresi linier.

\section{HASIL}

Berdasarkan penelitian yang telah dilakukan menunjukan adanya perbedaan varian dosis pemberian ekstrak ubi jalar ungu
(Ipoemoea batatas L.) terhadap kadar SOD tikus putih jantan (Rattus novergicus) galur wistar model aterosklerosis. Kadar SOD tikus masing-masing kelompok ditampilkan pada Tabel 1. Sementara, grafik rata-rata kadar SOD hewan coba tiap kelompok ditampilkan pada gambar 1.

Tabel 1. Kadar SOD Masing-masing Kelompok

\begin{tabular}{ccccccc}
\hline Kelompok & \multicolumn{5}{c}{ Kadar SOD } & $\begin{array}{c}\mathrm{R} \\
\end{array}$ \\
\cline { 2 - 6 } & 1 & 2 & 3 & 4 & 5 & \\
\hline $\mathrm{K}(-)$ & 11.51 & 14.46 & 12.73 & 12.12 & 12.34 & 12.632 \\
$\mathrm{~K}(+)$ & 10.29 & 10.18 & 11.29 & 11.01 & 10.79 & 10.712 \\
P1 & 11.23 & 11.46 & 11.84 & 12.07 & 11.84 & 11.688 \\
P2 & 11.84 & 12.23 & 11.68 & 11.79 & 12.84 & 12.076 \\
P3 & 12.79 & 12.96 & 14.79 & 12.34 & 12.23 & 13.022 \\
\hline
\end{tabular}

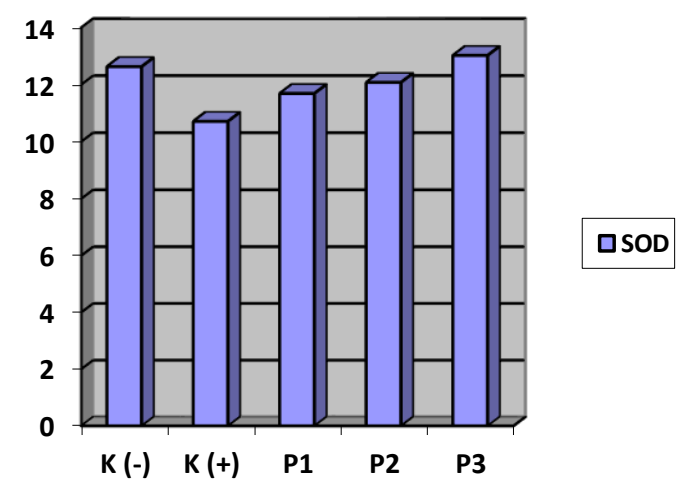

Gambar 1. Grafik Rata-rata Kadar SOD

Pada penelitian ini pemberian ekstrak ubi jalar ungu dengan dosis $24 \mathrm{mg} / \mathrm{hr}, 48 \mathrm{mg} / \mathrm{hr}$ dan $96 \mathrm{mg} / \mathrm{hr}$ yang sebelumnya telah diberi diet aterosklerosis, terbukti bahwa semakin tinggi pemberian dosis ekstrak ubi jalar ungu maka semakin tinggi pula kadar SOD tikus putih jantan.

Hasil uji One Way Anova menunjukkan nilai $\mathrm{p}=0,001$, karena syarat signifikan $\mathrm{p}<0,05$ sehingga pemberian ekstrak ubi jalar ungu menunjukkan perbedaan yang bermakna (signifikan) antara kadar SOD kelompok perlakuan pemberian ekstrak ubi jalar ungu dengan kadar SOD kelompok kontrol positif.

Untuk mengetahui hubungan ekstrak ubi jalar ungu (Ipomoea batatas L.) terhadap kadar SOD tikus putih jantan model aterosklerosis digunakan uji Korelasi Pearson. Pada uji korelasi pearson didapatkan sig $=$ 0,000 yang artinya terdapat hubungan yang bermakna antara pemberian ekstrak ubi jalar ungu dengan kadar SOD.

Selanjutnya dilakukan uji regresi untuk mengetahui seberapa besar pengaruh antara 
dosis ekstrak ubi jalar ungu terhadap kadar SOD tikus putih jantan model aterosklerosis. Persamaan tersebut yaitu : $\mathrm{y}=\mathrm{a}+\mathrm{b} \cdot \mathrm{x}$ atau $\mathrm{y}=$ $10.913+0.023(\mathrm{x})$; dimana $\mathrm{Y}$ adalah kadar SOD $(\mathrm{U} / \mathrm{mL})$ dan $\mathrm{X}$ adalah dosis ekstrak ubi jalar ungu $(\mathrm{mg} / \mathrm{hr})$.

\section{PEMBAHASAN}

Berdasarkan hasil penelitian didapatkan rata-rata kadar SOD pada kelompok kontrol positif yaitu $10,712 \mathrm{U} / \mathrm{mL}$, kadar tersebut merupakan kadar SOD terendah dan berdasar hasil analisis statitistik didapatkan berbeda signifikan jika dibanding dengan kontrol negatif yaitu kontrol normal pada penelitian ini.

Rendahnya kadar SOD tersebut disebabkan karena pada kelompok kontrol positif tikus hanya diinduksi diet aterosklerosis hal ini sesuai dengan penelitian Rui-Li et al tahun 2008 yaitu adanya peningkatan kadar LDL karena induksi diet ateroslerosis menyebakan penurunan kadar SOD. Rendahnya kadar SOD tersebut menunjukkan terjadinya stress oksidatif pada tikus akibat induksi aterosklerosis10.

Pada penelitian ini terbukti bahwa semakin tinggi pemberian dosis ekstrak ubi jalar ungu maka semakin tinggi pula kadar SOD tikus putih jantan. Peningkatan kadar SOD pada kelompok perlakuan tersebut diduga karena ekstrak ubi jalar ungu mengandung senyawa antosianin, beta glukan dan asam askorbat yang dapat meningkatkan kadar SOD dan menghambat stress oksidatif dengan mengaktifasi Nrf2-regulated phase II enzymes dalam tubuh. Penghambatan tersebut dapat mengakibatkan penurunan radikal superoksida sehingga dapat meningkatkan kadar SOD dalam darah11.

Jika dilihat dari hasil rata-rata kadar SOD pada kelompok perlakuan didapatkan kadar SOD pada perlakuan 3 yaitu dengan ekstrak ubi jalar ungu dosis $96 \mathrm{mg} / \mathrm{hr}$ menghasilkan kadar tertinggi dibanding dengan perlakuan 1 dan 2, Tingginya aktifitas antioksidan pada ubi jalar ungu yang digunakan sebagai parameter kerja antioksidan dalam tubuh merupakan salah satu faktor terjadinya kenaikan kadar SOD pada hewan coba12.

Berdasarkan hasil analisis post hoc didapatkan hasil bahwa pada perlakuan 3 yaitu dengan ekstrak ubi jalar ungu dosis $96 \mathrm{mg} / \mathrm{hr}$ tidak berbeda signifikan jika dibanding dengan kontrol negatif. Hal ini disebabkan karena kadar SOD pada tikus perlakuan 3 memiliki kadar yang hampir sama jika dibanding dengan kontrol negatif yang artinya kadar SOD pada tikus perlakuan 3 yang diinduksi diet aterosklerosis menghasilkan kadar SOD yang semakin meningkat setelah diberi ekstrak ubi jalar ungu dengan dosis $96 \mathrm{mg} / \mathrm{hr}$, bahkan peningkatan kadar SOD pada perlakuan 3 tersebut berdasarkan hasil statistik menunjukkan kadar SOD yang hampir sama jika dibanding dengan tikus pada kontrol negatif yaitu tikus yang hanya diberi pakan BR-1 sebagai tikus kontrol yang memiliki kadar SOD normal.

Pemberian ekstrak ubi jalar ungu dengan dosis $48 \mathrm{mg} / \mathrm{hr}$ dengan dosis $24 \mathrm{mg} / \mathrm{hr}$ maupun antara dosis $48 \mathrm{mg} / \mathrm{hr}$ dengan dosis $96 \mathrm{mg} / \mathrm{hr}$ tidak terdapat perbedaan yang signifikan terhadap rata-rata kadar SODnya. Hal ini disebabkan dosis pemberian ekstrak ubi jalar ungu pada penelitian ini memiliki rentang dosis yang sempit, sehingga pemberian dosis tersebut dapat meningkatkan rata-rata kadar SOD tetapi memiliki rentang rata-rata kadar SOD yang hampir sama.

Berdasarkan hasil Uji Regresi kandungan ekstrak ubi jalar ungu dapat meningkatkan kadar SOD dengan persentase sebesar 65,2\% dan sisanya yaitu sebesar $34,8 \%$ dapat dipengaruhi oleh faktor endogen dan eksogen. Faktor endogen meliputi faktor genetik, hormonal sedangkan faktor eksogen meliputi perlakuan hewan coba yang dapat mempengaruhi kondisi psikologis, adaptasi hewan coba, reaksi inflamasi saat proses sonde.

Dari berbagai fakta yang ditemukan pada penelitian ini dan melalui kajian statistika, maka hipotesis tentang terdapatnya pengaruh pemberian ekstrak ubi jalar ungu (Ipomoea batatas L.) terhadap kadar SOD pada tikus putih jantan (Rattus norvegicus) galur wistar 
diet aterosklerosis terbukti. Pengaruh ekstrak ubi jalar ungu pada penelitian ini berupa peningkatan pada kadar SOD.

\section{KESIMPULAN DAN SARAN}

Berdasarkan hasil dan pembahasan pada penelitian ini dapat diambil kesimpulan sebagai berikut:

1. Ekstrak ubi jalar ungu (Ipomoea batatas L.) terbukti berpengaruh secara bermakna, terhadap kadar superoksida dismutase (SOD) tikus putih jantan (Rattus novergicus) galur wistar model aterosklerosis.

2. Ekstrak ubi jalar ungu (Ipomoea batatas L.) dengan dosis $96 \mathrm{mg} / \mathrm{hari}$ memiliki pengaruh paling tinggi di antara kelompok perlakuan lainnya dalam meningkatkan kadar superoksida dismutase (SOD) serum tikus putih jantan (Rattus novergicus) galur wistar model aterosklerosis.

Berdasarkan kesimpulan telah dikemukan maka diberikan saran - saran yang dipergunakan dalam mengadakan perbaikan di masa yang akandatang, yaitu sebagai berikut:

1. Perlu dilakukan penelitian tentang pengaruh ubi jalar ungu (Ipomoea batatas L.) terhadap kadar SOD tikus putih jantan dengan metode lain yang lebih mudah untuk dikonsumsi di masyarakat seperti ubi rebus.

2. Perlu dilakukan penelitian lebih lanjut dengan variasi dosis ekstrak ubi jalar ungu dengan rentang dosis yang lebih luas dalam mencari efek optimal untuk meningkatkan kadar SOD pada tikus putih jantan.

\section{DAFTAR PUSTAKA}

1. Majid A. Penyakit jantung koroner: patofisiologi, pencegahan, dan pengobatan terkini. e-USU repository Universitas Sumatera Utara. 2007. pp.154. Unpublished.

2. Salim AY, Nurrohmah A. Hubungan olahraga dengan penyakit jantung koroner di RSUD Dr Moewardi. GASTER. 2013;10(1):48-56.

3. World Health Organization. Global atlas on cardiovascular disease prevention and control. 2012

4. Riskesdas. Riset Kesehatan Dasar Badan Penelitian dan Pengembangan Kesehatan Kementerian Kesehatan Indonesia. Kementerian Kesehatan RI: Jakarta. 2013.

5. Mitra S, Goyal T, Mehta JL. Oxidized LDL, LOX-1 and atherosclerosis. Cardiovasc Drugs Ther. 2011;25(5): 419429.

6. Winarsi H. Antioksidan alami \& radikal bebas : potensi dan aplikasinya dalam kesehatan. Cetakan ke-4. Yogyakarta : Penerbit Kanisius. 2010. pp. 12 15,19,29-36,86-106.

7. Jaya, Evi FP. Pemanfaatan antioksidan dan betakaroten ubi jalar ungu pada pembuatan minuman non-beralkohol. Media Gizi Masyarakat Indonesia. 2013;2(2):54-57.

8. Natalia SL, Haryono S, Budhi P. Ubi jalar ungu papua sebagai sumber antioksidan. Universitas Kristen Satya Wacana, unpublished.2012

9. Muller H, Lindman AS, Brantsaeter AL, Pedersen JL. The serum ldl/hdl cholesterol ratio is influenced more favorably by exchanging saturated with unsaturated fat than by reducing saturated fat in the diet of women. J. Nutr. 2003;133(1):78-83.

10. Rui-Li Y, Yong-Hui S, Gang H, Wu L, Guo-Wei L. Increasing oxidative stress with progressive hyperlipidemiain human: relation between malondialdehyde and atherogenic index. J Clin Biochem Nutr. 2008;43(3):154-158.

11. Speciale A, Anwar S, Canali R, Chirafisi J, Saija A, Firgili F, et al. Cyanidin- 3O- glucoside counters the response to TNF- alpha of endothelial cells by activating Nrf2 pathway. Mol Nutr Food Res. 2013;57(11):1979-1987.

12. Panda V, Sonkamble M. Anti-ulcer activity of Ipomoea batatas tubers (sweet potato). Functional Foods in Health and Disease. 2012;2(3):48-61. 